\title{
UJI AKTIVITAS SENYAWAANTIOKSIDAN DARI RUMPUT LAUT Halymenia harveyana DAN Eucheuma cottonii
}

\author{
Th. Dwi Suryaningrum*), Thamrin Wikanta*), dan Hendy Kristiana*)
}

\begin{abstract}
ABSTRAK
Penelitian uji aktivitas senyawa antioksidan dari rumput laut Halymenia harveyana dan Eucheuma cottonii telah dilakukan. Aktivitas antioksidan dan uji toksisitasnya diamati terhadap ekstrak kasar, fraksi n-heksana, dan fraksi metanol dari rumput laut segar dan kering, serta identifikasi senyawa aktif menggunakan GC-MS. Hasil penelitian menunjukkan bahwa aktivitas antioksidan ekstrak rumput laut segar lebih tinggi dari pada ekstrak rumput laut kering. Ekstrak fraksi metanol dari Halymenia harveyana segar memiliki aktivitas antioksidan yang paling poten. Pada kedua jenis rumput laut tersebut, toksisitas ekstrak dari sampel kering lebih tinggi dibandingkan dengan ekstrak dari rumput laut segarnya. Ekstrak Halymenia harveyana mengandung senyawa-senyawa antioksidan mirip BHT (butil hidroksi toluen), ester dan hidrokarbon aromatis, demikian pula ekstrak Eucheuma cottonii banyak mengandung antioksidan tetapi mempunyai toksisitas yang tinggi terhadap Artemia salina.

\section{ABSTRACT: Screening of antioxidative substance from seaweeds Halymenia harveyana and Eucheuma cottonii. By: Th. Dwi Suryaningrum, Thamrin Wikanta, and Hendy Kristiana}

Research on antioxidative substance from seaweeds Halymenia harveyana and Eucheuma cottonii has been carried out. Antioxidative activity and toxicity assay were measured against crude extract, $n$-hexane, and methanol fraction of fresh and sundried samples, and identification of the active substance was done using GC-MS. The result showed that antioxidative activity of fresh seaweed extract was higher than sundried seaweed extract. Methanol fraction extract of fresh Halymenia harveyana had the most potent antioxidative activity. For both seaweeds, the toxicity of extract from sundried seaweed was higher than extract from fresh seaweed. Halymenia harveyana extract contained antioxidative agent similar to BHT (Butyl hydroxy toluen), ester and aromatic hydrocarbon, Eucheuma cottonii also contained a lot of antioxidative agent but had high toxicity against Artemia salina.
\end{abstract}

KEYWORDS: $\quad$ antioxidative agent, toxicity, Halymenia harveyana, Eucheuma cottonii

\section{PENDAHULUAN}

Rumput laut secara tradisional telah lama digunakan sebagai bahan makanan dan obat-obatan, karena kaya akan mineral, elemen makro dan elemen mikro lainnya. Beberapa jenis rumput laut mengandung mineral penting yang berguna untuk metabolisme tubuh seperti iodin, calsium dan selenium (Burtin, 2006). Di beberapa daerah pesisir, rumput laut telah digunakan sebagai bahan obat rematik, anti diare, obat cacing, gondok, dan penambah darah (Anon., 1995; Nontji, 1996). Di Jepang rumput laut merupakan menu sehari-hari, sehingga orang Jepang jarang sekali terkena penyakit kanker dibandingkan dengan orang Jepang yang telah bermigrasi ke Amerika dimana rumput laut tidak lagi menjadi menu harian mereka (Arabei, 2000). Uji aktivitas antioksidan dengan menggunakan metoda 1,1-phenil-2-pikrilhidrazil (DPPH) terhadap edible seaweed seperti nori (Phorphyra sp), kumbu (Laminaria sp), wakame (Undaria sp) dan hijiki (Hijikia sp) menunjukkan bahwa rumput laut tersebut mengandung antioksidan yang cukup tinggi ( Ismail \& Hong, 2002). Demikian juga halnya dengan Gelidium amansii, Gloiosiphonia capillaris, Polysiphonia urceolata, Sargassum kjellmanianum, Desmarestia viridis, dan Rhodomela teres yang menunjukkan adanya aktivitas antioksidan yang kuat (Yan et al., 1998). Kandungan antioksidan pada rumput laut terutama berupa senyawa antioksidatif polifenol. Dari hasil penelitian isolasi senyawa polifenol dari rumput laut Halimada $s p$ yang tergolong dalam rumput laut 
coklat diperoleh bermacam-macam senyawa antara lain catechin, epicatechin, epigallocatechin, catechin gallate, epicatechin gallate, epigallocathecin gallate, rutin, quercitrin, hesperidin, myricetin, morin, luteolin, quercetin, apigeini, kaempferol, dan baicalein (Siriwardhana et al., 2003). Sedangkan Misonou et al. (2003) melaporkan bahwa jenis rumput laut merah Porphyra yeszoensis mengandung senyawa antioksidan poten yang dapat menghambat penetrasi sinar UV yang kuat ke dalam jaringan atau sel. Menurut Kardono (2004) terdapat sekitar 2500 jenis senyawa bioaktif dari laut yang telah berhasil diisolasi dan diidentifikasi, dan $93 \%$ di antaranya diperoleh dari rumput laut.

Antioksidan merupakan senyawa yang dapat menetralkan atau meredam radikal bebas, serta menghambat terjadinya oksidasi pada sel tubuh, sehingga dapat mencegah atau mengurangi terjadinya kerusakan sel (Abdul, 2003). Radikal bebas merupakan atom atau molekul yang memiliki satu atau lebih elektron yang tidak berpasangan yang dapat menarik elektron dari senyawa lain sehingga terbentuk radikal bebas yang baru dan menyebabkan terjadinya reaksi berantai. Reaksi berantai radikal bebas antara lain dapat merusak molekul makro pembentuk sel yaitu: protein, karbohidrat lemak dan deoxyribo nucleic acid (DNA) (Anon., 2004). Akibatnya sel menjadi rusak, dan menyebabkan berbagai jenis penyakit, seperti: kanker, anemia, asma, artritis, inflamasi, degerenasi syaraf, parkinson, dan proses penuaan dini (Polterait,1997). Oleh karena itu antioksidan sangat bermanfaat bagi kesehatan dan berperan penting untuk mempertahankan mutu produk pangan.

Rumput laut Halymenia harveyana dan Eucheuma cottonii telah dimanfaatkan oleh masyarakat pesisir sebagai bahan makanan terutama untuk sayuran atau manisan. Menurut Arabei (2000), rumput laut dapat bermanfaat untuk membersihkan usus, memperbaiki proses pencernaan dan penyerapan sari makanan serta memperbaiki peristaltik usus. Rumput laut juga merupakan sumber vitamin terutama vitamin $B, C$ dan E . Kedua jenis rumput laut tersebut tergolong dalam kelas Rhodophyceae atau rumput laut merah yang mengandung pigmen fikoeritin, karotenoid, klorofil a, senyawa organik dan anorganik dan serat kasar (Jimenez-Escrig \& Goni, 1999). Hasil penelitian terbaru menunjukkan bahwa karotenoid pada rumput laut merupakan antioksidan yang dapat berfungsi untuk melindungi berbagai macam penyakit dan stres. (Okuzumi di dalam Burtin, 2006). Selama ini informasi mengenai aktivitas dan kandungan antioksidan pada kedua jenis rumput laut tersebut belum ada. Dalam penelitian ini akan dilakukan uji aktivitas dan identifikasi senyawa antioksidan yang terdapat pada kedua jenis rumput laut tersebut, sehingga diperoleh informasi yang dapat menjadi data dasar dalam upaya pemanfaatan rumput laut sebagai makanan fungsional dan sumber antioksidan untuk obat dan industri makanan.

\section{BAHAN DAN METODE}

\section{Bahan}

Bahan yang digunakan dalam penelitian ini adalah rumput laut Halymenia harveyana yang diperoleh dari Pantai Nusa Dua, Denpasar, Bali dan Eucheuma cottonii yang diperoleh dari Rembang, Jawa Tengah. Rumput laut segar dicuci dan dibersihkan dari kotoran yang menempel dengan menggunakan air laut. Masing-masing jenis rumput laut tersebut kemudian dimasukkan ke dalam kantong plastik dan diberi metanol teknis sampai terendam untuk dibawa ke Jakarta. Di laboratorium rumput laut dibagi menjadi 2 bagian, bagian pertama ditimbang masing-masing sebanyak $1 \mathrm{~kg}$ langsung dimaserasi dan bagian kedua setelah ditimbang seberat $1 \mathrm{~kg}$ dikeringkan di bawah sinar matahari. Sedangkan bahan pembantu yang digunakan adalah metanol p.a. dan teknis, heksan pa. dan teknis, dimetil sulfoksida (DSMO), 1,1-phenil2-pikrilhidrazil (DPPH), akuades, dan kista Artemia.

\section{Metode}

Metode yang digunakan dalam penelitian ini adalah metode yang bersifat eksploratif deskriptif (non hipotesis). Rumput laut segar dipotong-potong dengan ukuran $\pm 1 \mathrm{~cm}$, kemudian dimaserasi dengan menggunakan metanol teknis dengan perbandingan metanol dan rumput laut 1:1 (b/v) selama 24 jam. Sedangkan untuk rumput laut kering, maserasi dilakukan selama 15 hari agar masa bioaktif dapat dikeluarkan dari thallusnya yang padat. Rumput laut kemudian disaring dengan menggunakan kertas saring Whatman No. 41 dan filtrat ditampung dalam erlenmeyer. Masing-masing sampel dimaserasi ulang sampai 2 kali selama 24 jam dengan menggunakan metanol dengan perbandingan yang sama. Ekstrak metanol yang terkumpul kemudian dievaporasi dengan menggunakan rotary evaporator pada suhu $30^{\circ} \mathrm{C}$ hingga pelarut menguap, kemudian dikeringkan dengan menggunakan freeze dryer sehingga diperoleh ekstrak kasar kering yang masih mengandung garam organik.

Untuk menghilangkan garam, ekstrak kasar dilarutkan dengan menggunakan metanol p.a lalu didekantasi berulang-ulang hingga warna putih yang menunjukkan adanya garam pada pelarut hilang. Larutan kemudian dievaporasi ulang dan dikeringkan kembali dengan menggunakan freeze dryer hingga didapatkan ekstrak kasar kering yang bebas garam. 
Fraksinasi dilakukan untuk memisahkan senyawa sesuai dengan polaritasnya dengan metode partisi menggunakan pelarut organik metanol (polar) dan nheksan (non polar). Ekstrak kasar yang telah bebas garam dilarutkan dalam metanol p.a sehingga diperoleh ekstrak kental metanol. Ekstrak kental metanol tersebut kemudian dipartisi sebanyak 3 kali dengan $200 \mathrm{~mL}$ campuran metanol : n-heksan (2:3), kemudian dikocok. Ekstrak kemudian dievaporasi hingga diperoleh ekstrak kental n-heksan. Ekstrak kental n-heksan dikeringkan dengan freeze dryer hingga diperoleh fraksi n-heksan. Sedangkan residunya merupakan ekstrak metanol, setelah dievaporasi dan dikeringkan dengan freeze dryer akan menjadi fraksi metanol. Diagram alir penapisan antioksidan dapat dilihat pada Gambar 1.

\section{Pengamatan}

Pengamatan yang dilakukan meliputi rendemen ekstrak kasar, rendemen ekstrak kasar setelah desalting dan rendemen setelah fraksinasi. Pengujian ekstrak kasar bebas garam dan sampel yang telah difraksinasi dengan metanol dan n-heksan diuji aktivitas antioksidan dengan metoda 1,1-phenil-2pikrilhidrazil atau DPPH (Oke \& Hamburger, 2002). Pengujian dilakukan pada 4 konsentrasi yaitu $25 \mathrm{ug} /$ $\mathrm{mL}, 50 \mathrm{ug} / \mathrm{mL}, 100 \mathrm{ug} / \mathrm{mL}$ dan $200 \mathrm{ug} / \mathrm{mL}$ dengan vitamin $\mathrm{C}$ sebagai kontrol. Uji toksisitas dilakukan dengan metoda Brine Shrimp Lethality Test atau BSLT (Meyer et al., 1982). Pengujian tingkat toksisitas juga dilakukan pada 4 titik konsentrasi yaitu $5 \mathrm{ug} / \mathrm{mL}, 50 \mathrm{ug} / \mathrm{mL}, 250 \mathrm{ug} / \mathrm{mL}$ dan $1000 \mathrm{ug} / \mathrm{mL}$. Masing-masing pengujian diulang sebanyak 3 kali. Identifikasi senyawa aktif dilakukan dengan menggunakan Gas Chromatografi Mass
Spectrofotometer (GC-MS) QP-2010 Shimadzu terhadap ekstrak rumput laut $E$. cottonii dan $H$. halymenia segar fraksi metanol (polar). Ekstrak di larutkan dalam metanol p.a dan diidentifikasi untuk mengetahui pola fragmentasinya.

\section{HASIL DAN BAHASAN}

\section{Rendemen}

Rendemen senyawa bioaktif diamati terhadap ekstrak kasar bergaram dan ekstrak kasar setelah desalting, hasilnya dapat dilihat pada Tabel 1. Rendemen ekstrak kasar yang didapat sangat kecil. Walaupun rendemennya kecil, apabila senyawa bioaktif yang dihasilkan bersifat sangat poten maka tetap akan mempunyai nilai ekonomis.

Rendemen ekstrak senyawa bioaktif yang diperoleh dari sampel segar pada E.cottonii lebih besar bila dibandingkan dengan $H$. harveyana. Namun jika ekstraksi dilakukan pada sampel kering keduanya menghasilkan rendemen yang tidak banyak berbeda. Dalam keadaan segar rumput laut $E$. cottonii mempunyai thallus lebih tebal yang mengandung massa yang lebih banyak bila dibandingkan dengan $H$. harveyana yang mempunyai thallus berbentuk pipih seperti pita. Perbedaan ini diduga menyebabkan perbedaan rendemen senyawa bioaktif yang dihasilkan.

Pada $H$. harveyana pengeringan tidak menyebabkan penurunan rendemen secara berarti dari $1,48 \%$ menjadi $1,04 \%$ (turun sebesar $29 \%$ ), tetapi pada $E$. cottonii pengeringan menyebabkan penurunan rendemen yang cukup tajam, yaitu dari $5,79 \%$ menjadi $1,03 \%$ (turun sebesar $82 \%$ ). Pada

Tabel 1. Rata-rata rendemen ekstrak kasar rumput laut sebelum dan sesudah desalting*)

Table 1. Average yield of seaweed crude extract before and after desalting")

\begin{tabular}{lcc}
\hline \multirow{2}{*}{ Sampel/Sample } & \multicolumn{2}{c}{ Rendemen/Yield (\%) } \\
\cline { 2 - 3 } & $\begin{array}{c}\text { Sebelum desalting/ } \\
\text { Before desalting }\end{array}$ & $\begin{array}{c}\text { Sesudah desalting/ } \\
\text { After desalting }\end{array}$ \\
\hline H. harveyana: & $1.48 \pm 0.12$ & $0.57 \pm 0.04$ \\
Sampel segar/Fresh sample & $1.04 \pm 0.08$ & $0.34 \pm 0.06$ \\
Sampel kering/Sundried sample & $5.79 \pm 0.49$ & $2.01 \pm 0.17$ \\
E. cottonii: & $1.03 \pm 0.26$ & $0.32 \pm 0.06$ \\
Sampel segar/Fresh sample & Sampel kering/Sundried sample &
\end{tabular}

*) Rata-rata dari 3 ulangan/Average of three replications 


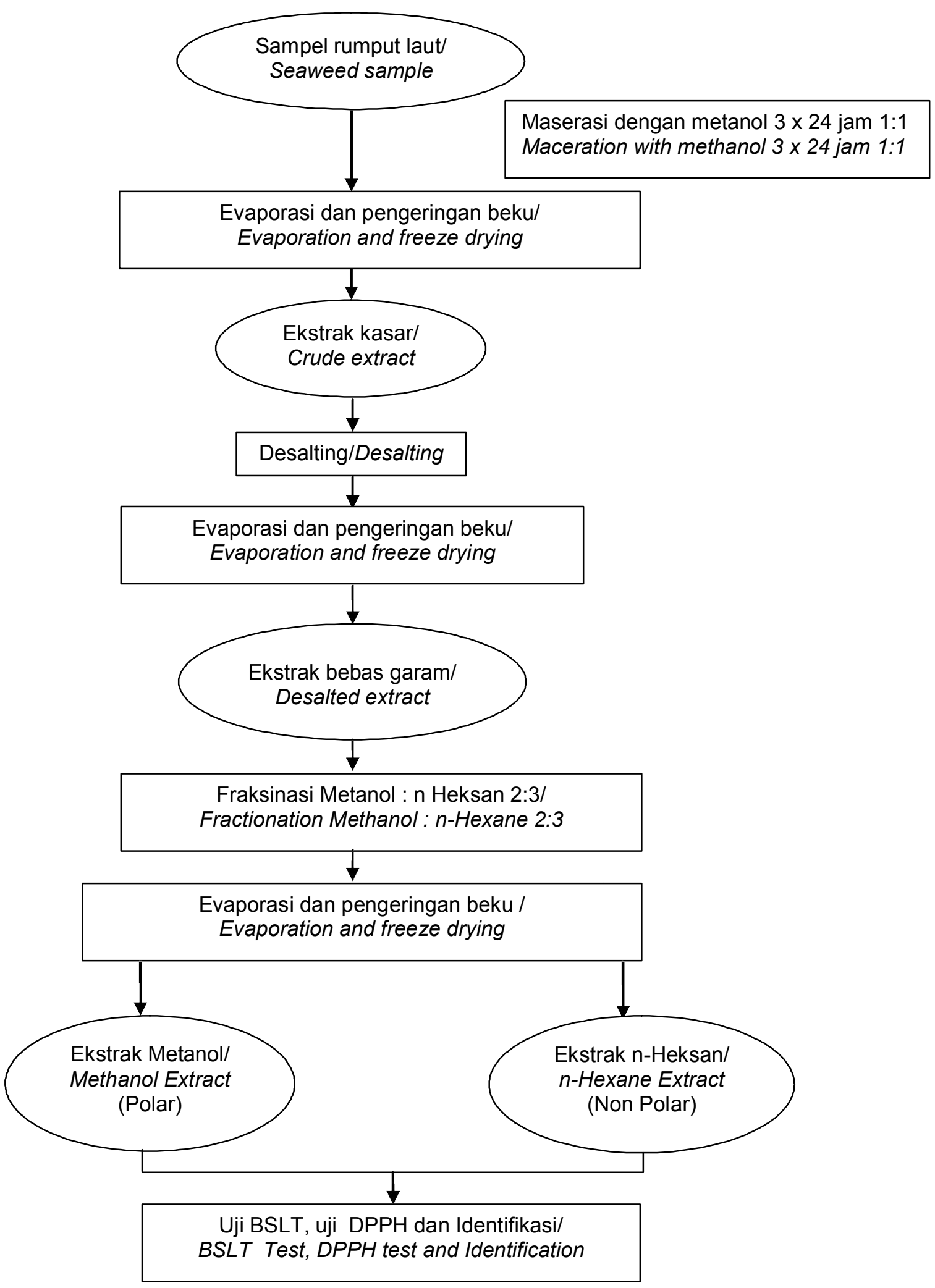

Gambar 1. Diagram alir skrining antioksidan dari rumput laut.

Figure 1. Flow chart of antioxidant screening from seaweed. 
E.cotonii yang merupakan penghasil karaginan, proses pengeringan menyebabkan hilangnya gugus hidroksil dan membentuk ikatan hidrogen yang kuat yang menyebabkan masa bioaktif tidak mudah untuk dilarutkan, sehingga rendemen yang dihasilkan dari rumput laut kering menurun sangat tajam dibandingkan dengan rumput laut segar.

Setelah proses desalting, rendemen yang diperoleh menjadi semakin rendah, yang menunjukkan bahwa ekstrak yang diperoleh mengandung lebih banyak garam anorganik yang tidak larut dari pada senyawa yang dapat larut. Keberadaan garam di dalam ekstrak kasar senyawa bioaktif tergantung dari banyaknya garam yang ada di dalam rumput laut. Persentase berkurangnya ekstrak kasar karena desalting pada sampel segar lebih banyak dibandingkan sampel kering. Pada sampel segar penurunan rendemen setelah desalting pada E.cottonii lebih besar dibandingkan dengan $H$. harveyana. Dalam keadaan basah thallus rumput laut $E$. cottonii lebih banyak mengandung air laut dibandingkan dengan thallus $H$. harveyana yang berbentuk pipih seperti pita, sehingga garam tidak banyak yang terekstrak pada saat maserasi.

Setelah proses pengeringan rumput laut, rendemen ekstrak kasar yang diperoleh dari kedua jenis sampel rumput laut tidak jauh berbeda, hal ini menunjukkan bahwa jumlah ekstrak kasar senyawa bioaktif pada kedua jenis rumput laut kering relatif sama. Reduksi ekstrak kasar karena proses desalting terhadap ekstrak dari sampel kering lebih banyak dibandingkan dengan dari sampel segar. Senyawa organik yang terdapat dalam sampel diduga mengalami reaksi atau asosiasi dengan garam-garam yang terdapat di dalam sampel pada saat proses pengeringan sehingga terbentuk senyawa-senyawa garam organologam yang tidak larut dalam pelarut organik. Peristiwa ini menjadikan rendemen ekstrak kasar lebih rendah dibandingkan dengan dari sampel segar.

Hasil fraksinasi kedua jenis rumput laut, baik segar maupun kering, mengandung fraksi metanol (polar) lebih banyak dibandingkan dengan n-heksan (non polar). Hal ini menunjukkan bahwa ekstrak senyawa bioaktif lebih banyak yang bersifat polar dari pada non polar (Tabel 2). Dalam penelitian ini proses fraksinasi menyebabkan hilangnya rendemen, karena banyak nya produk yang menempel pada dinding kaca pada saat evaporasi dan pengeringan beku, yang tidak dapat diambil sehingga menurunkan rendemen yang diperoleh.

\section{Aktivitas Antioksidan}

Uji aktivitas antioksidan dengan menggunakan radikal 1,1-difenil-2-pikrilhidrazil (DPPH) dapat dilihat pada Gambar 2 dan 3. Aktivitas antioksidan ekstrak rumput laut $H$. harveyana dan $E$. cottonii dari sampel segar bersifat lebih poten dibandingkan dengan ekstrak dari sampel kering. Hal ini disebabkan senyawa antioksidan tidak tahan terhadap panas matahari dan sinar UV, sehingga proses pengeringan menyebabkan rusaknya senyawa antioksidan pada rumput laut tersebut.

Rata-rata aktivitas antioksidan ekstrak rumput laut E. cottonii lebih rendah bila dibandingkan dengan ekstrak rumput laut $H$. harveyana. Secara umum ekstrak yang diperoleh menunjukkan aktivitas antioksidan yang rendah. Aktivitas yang paling tinggi terhadap radikal bebas DPPH ditunjukkan pada fraksi

Tabel 2. Fraksi polar dan nonpolar dari ekstrak kasar rumput laut

Table 2. Polar and non polar fractions from seaweed crude extract

Fraksi (\% ekstrak kasar)/Fraction (\% crude extract)

\begin{tabular}{lcc}
\cline { 2 - 3 } \multicolumn{1}{c}{ Sampel/Sample } & $\begin{array}{c}\text { Polar/Polar } \\
\text { Metanol/Methanol }\end{array}$ & $\begin{array}{c}\text { Nonpolar/Nonpolar } \\
\text { n-heksan/n-hexane }\end{array}$ \\
\hline H. harveyana: & $59.80 \pm 0.43$ & $30.40 \pm 3.33$ \\
Segar/Fresh sample & $48.70 \pm 3.20$ & $22.87 \pm 2.25$ \\
Kering/Sundried sample & & \\
E. cottonii: & $45.60 \pm 1.80$ & $40.60 \pm 1.90$ \\
Segar/Fresh sample & $64.80 \pm 2.26$ & $25.00 \pm 2.66$ \\
Kering/Sundried sample &
\end{tabular}




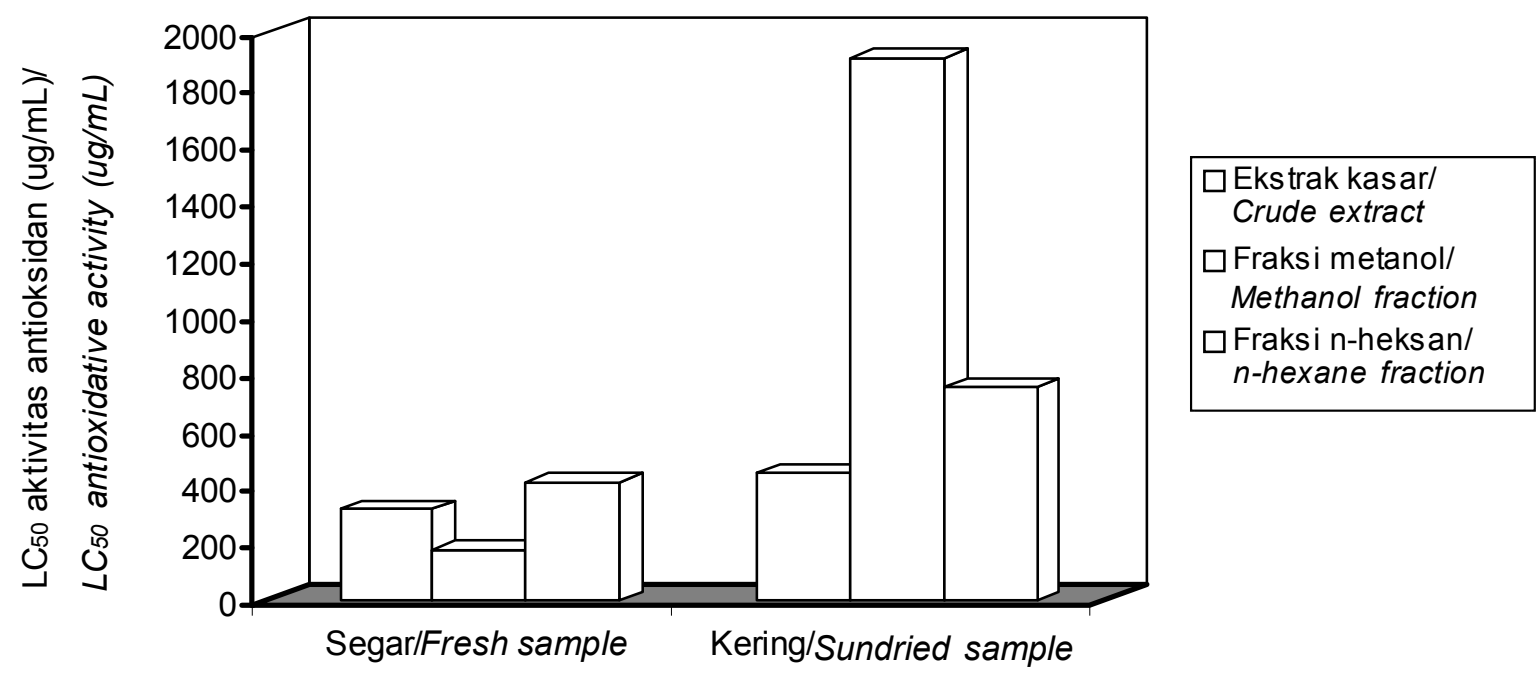

Gambar 2. Aktivitas antioksidan dari ekstrak $H$. harveyana segar dan kering.

Figure 2. Antioxidative activity of fresh and sun dried $\boldsymbol{H}$. harveyana extracts.

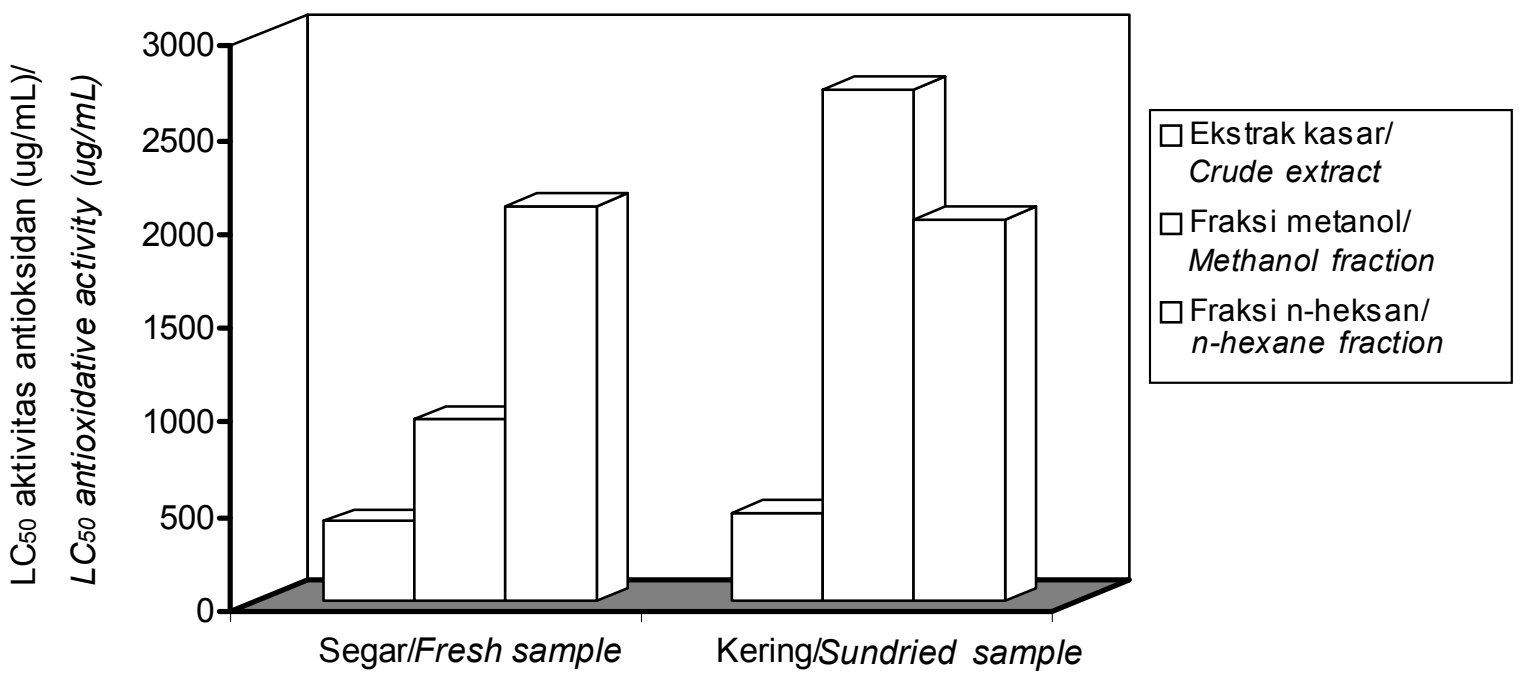

Gambar 3. Aktivitas antioksidan dari ekstrak E. cottonii.

Figure 3. Antioxidative activity of fresh and sundried E. cottonii extracts.

metanol dari sampel $H$. harveyana segar dengan nilai $\mathrm{LC}_{50}$ sebesar $176,50 \mathrm{ug} / \mathrm{mL}$. Ini berarti pada konsentrasi 176,50 ug/mL baru dapat menghambat $50 \%$ aktifitas radikal DPPH. Aktivitas antioksidan fraksi metanol dari $H$. harveyana bersifat lebih poten dibandingkan dengan fraksi metanol dari E. cottonii. Hal ini dapat dijelaskan, secara visual saja terlihat bahwa $H$. harveyana mengandung pigmen karoten yang tinggi dan klorofil yang rendah, yang berwarna merah maroon. Sedangkan pada E. cottonii warnanya kuning pucat atau sedikit agak hijau yang berarti kandungan karoten rendah dan klorofil agak tinggi. Senyawa karoten dan klorofil termasuk golongan senyawa antioksidan poten yang berperan sebagai 
fotoreseptor pada tanaman. Kandungan karoten itulah yang menjadikan $H$. harveyana bersifat sebagai antioksidan yang lebih poten dibandingkan dengan E. cottonii.

Menurut Jun et al. (2003) aktivitas antioksidan tergolong lemah jika nilai $\mathrm{LC}_{50}$ lebih dari $150 \mathrm{ug} / \mathrm{mL}$. Jika dibandingkan dengan aktivitas vitamin $\mathrm{C}\left(\mathrm{LC}_{50}\right.$ $18,2 \mathrm{ug} / \mathrm{mL}$ ), aktifitas antioksidan pada ekstrak rumput laut kekuatannya hanya sepersepuluhnya, sehingga aktivitas antioksidan pada kedua jenis rumput laut tersebut tergolong lemah. Hasil uji aktivitas antioksidan juga menunjukkan bahwa fraksinasi menyebabkan turunnya aktivitas antioksidan yang dihasilkan. Hal ini ditunjukkan dengan makin besarnya nilai $\mathrm{LC}_{50}$ dari masing-masing fraksi dibandingkan dengan ekstrak kasarnya kecuali pada ekstrak $H$. harveyana segar fraksi metanol. Ekstrak yang diperoleh dari perlakuan ini memiliki aktivitas yang paling poten dibandingkan dengan lainnya. Kelemahan dari antioksidan di antaranya adalah sifatnya yang mudah rusak bila terpapar oksigen, cahaya, suhu tinggi, dan pengeringan. Penggunaan bahan pelarut yang tidak tepat juga dapat merusak aktivitas antioksidan yang ada. Jan et al. (2001) menyatakan bahwa penggunaan pelarut yang sama dapat memberikan hasil yang sangat berbeda walaupun partikel dan stabilitas substrat sampel yang diekstraksi hampir sama.

\section{Uji Toksisitas}

Uji toksisitas tahap awal yang menggunakan hewan uji Artemia salina (metode BSLT) dilakukan terhadap ekstrak kasar $H$. harveyana dan $E$. cottonii, dan terhadap ekstrak hasil fraksinasinya. Hasil uji menunjukkan bahwa ekstrak kasar maupun hasil fraksinasi sampel kering pada kedua jenis rumput laut tersebut, memiliki toksisitas yang lebih baik dibandingkan dengan sampel segar. Terlihat pada Gambar 4 dan 5 pada ekstrak $H$. harveyana dan $E$. cottonii sampel kering bersifat lebih toksik dibandingkan dengan sampel segar. Hal ini diduga bahwa pengeringan dapat menyebabkan terbentuknya senyawa yang bersifat toksik terhadap Artemia salina karena terpapar sinar UV pada saat penjemuran dengan sinar matahari.

Ekstrak kasar dari E. cottonii lebih toksik dibandingkan dengan ekstrak kasar dari $H$. harveyana. Fraksinasi ekstrak kasar dari $H$. harveyana dengan menggunakan pelarut metanol dan n-heksan baik terhadap sampel segar maupun kering menyebabkan meningkatnya toksisitas senyawa hasil fraksinasinya, namun fraksi metanol lebih poten bila dibandingkan dengan fraksi n-heksan. Hal ini menunjukkan bahwa ekstrak $H$. harveyana mengandung senyawa polar yang bersifat lebih toksik dibandingkan dengan senyawa non polar.

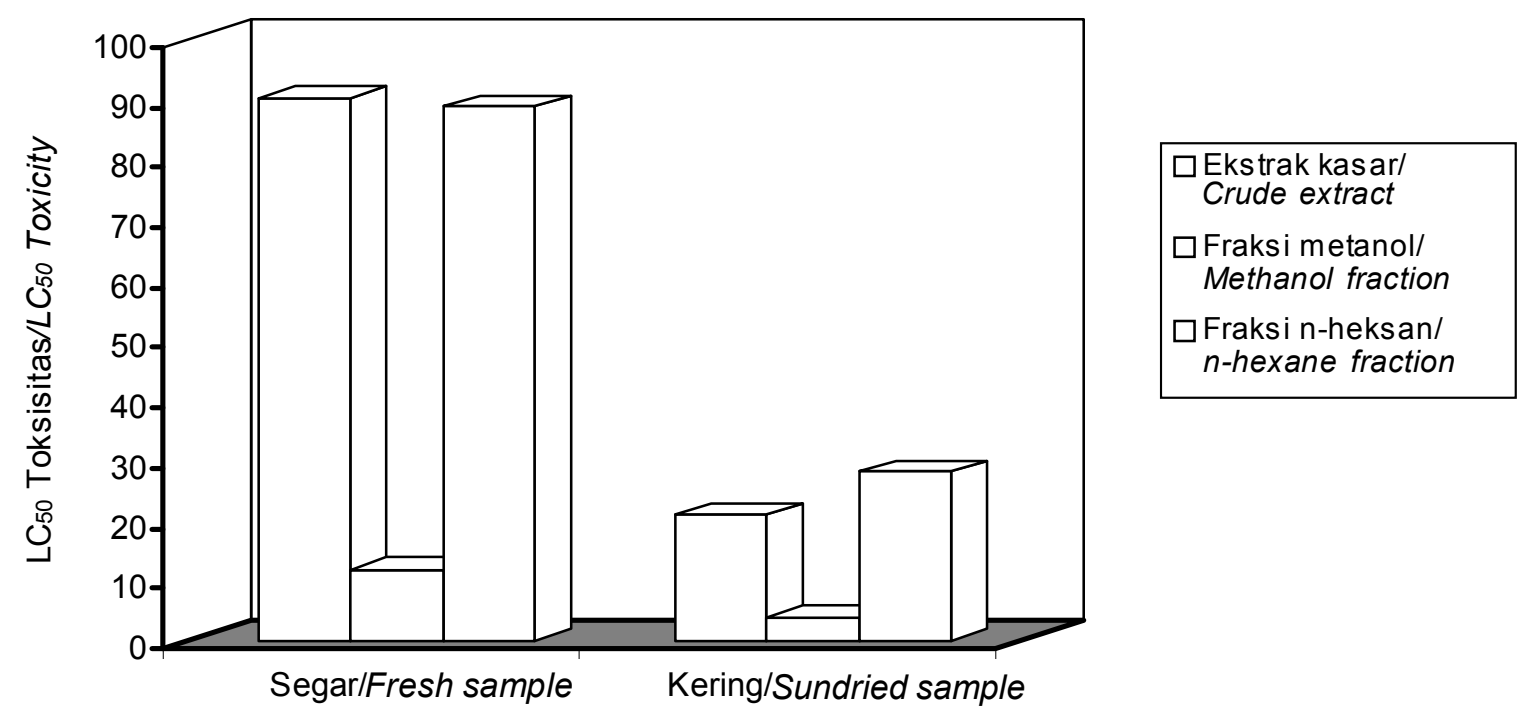

Gambar 4. Toksisitas ekstrak H. harveyana dengan metode BSLT.

Figure 4. Toxicity assay of $\boldsymbol{H}$. harveyana extract with BSLT method. 


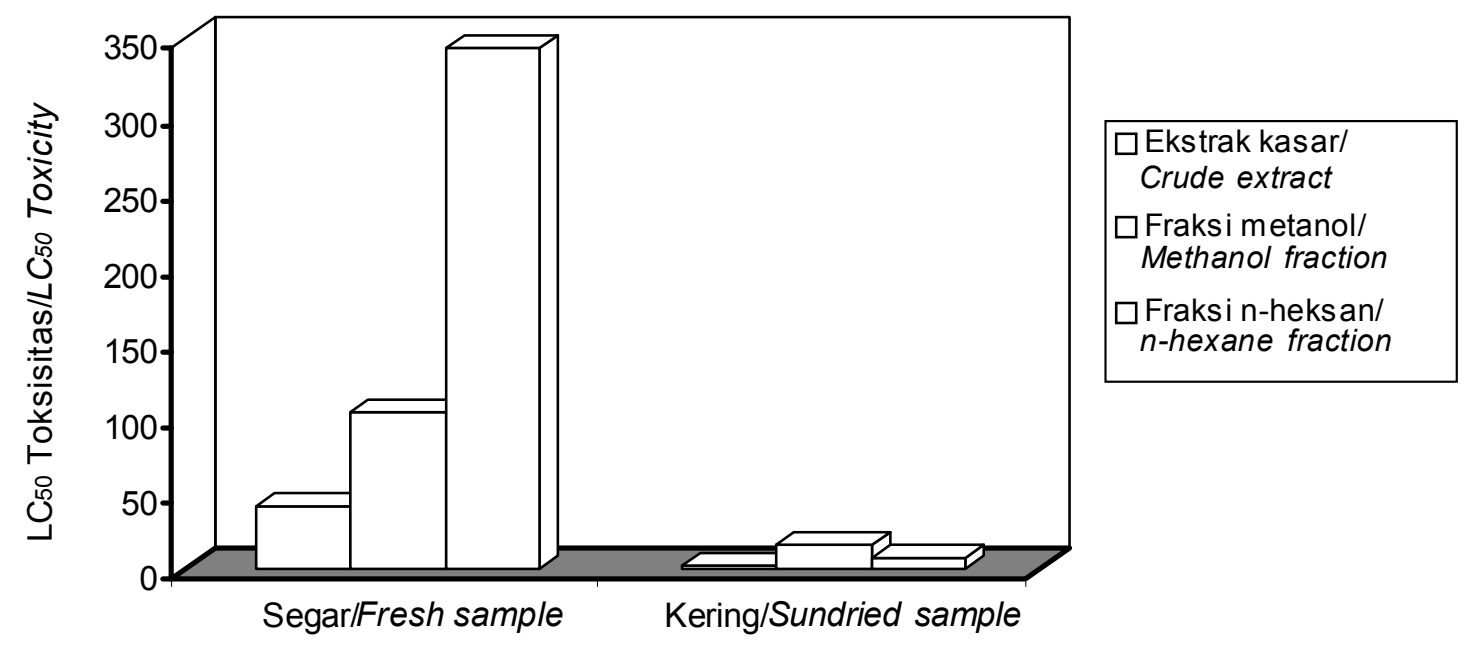

Gambar 5. Toksisitas ekstrak E. cottonii dengan metode BSLT

Figure 5. Toxicity assay of E. cottonii extract with BSLT method

Pada E.cottonii fraksinasi baik dengan metanol maupun n-heksan justru menurunkan toksisitas ekstrak yang diperoleh. Hal ini menunjukkan adanya efek sinergi antara fraksi polar dan non polar dalam sifat toksiknya apabila kedua fraksi tersebut digabung.

Suatu senyawa dikatakan bersifat sangat toksik apabila memiliki nilai $\mathrm{LC}_{50}<30 \mathrm{ug} / \mathrm{mL}$ (Meyer et al., 1982). Dari hasil penelitian ini ekstrak kedua jenis rumput laut tersebut bersifat sangat toksik apabila diekstrak dari sampel kering. Sedangkan pada sampel segar $H$. harveyana, ekstrak senyawa bioaktif akan bersifat sangat toksik setelah difraksinasi dengan metanol.

Ekstrak kering pada kedua jenis rumput laut tersebut mempunyai LC $_{50}$ berkisar antara 1,63-27,94 $\mathrm{ug} / \mathrm{mL}$. Mc Laughlin \& Roger (1998) menyatakan bahwa ada korelasi positif antara toksisitas terhadap Artemia salina (BSLT) dengan sitotoksisitas terhadap sel kanker human nasopharyngeal carcinoma. Dari hasil penelitian ini diketahui bahwa ekstrak kasar dan fraksi metanol dari $E$. cottonii kering dan $H$. harveyana kering mempunyai prospek yang potensial untuk diteliti lebih lanjut sebagai sumber senyawa antikanker. Para peneliti melaporkan bahwa rumput laut merah mengandung senyawa bioaktif antitumor, seperti jenis rumput laut Polysiphonia lanosa yang mengandung senyawa derivat fenol yang terbrominasi, dan memiliki sifat sitotoksik yang poten terhadap sel lestari tumor colon DLD-1 dan HGT-116 (Shoeib et al., 2004). Peneliti lain mengemukakan bahwa jenis rumput laut merah, Ceratodyction spongium, dari pantai Pulau Biaro, Indonesia, dilaporkan mengandung senyawa trans-trans-ceratospongamida yang merupakan inhibitor poten sebagai anti inflamasi (Lik Tong Tan et al., 2000).

\section{Identifikasi senyawa bioaktif dengan Gas Chromatography-Mass Spektrometer (GC- MS)}

Identifikasi untuk menentukan profil senyawa antioksidan dalam rumput laut dilakukan dengan menggunakan GC-MS terhadap fraksi metanol (polar) hasil ekstraksi $E$. cottonii dan $H$. harveyana segar. Hasilnya berupa kromatogram yang ditunjukkan dengan suatu grafik dengan beberapa puncak, setiap satu puncak mewakili satu jenis senyawa. Ekstrak $H$. harveyana mengandung 20 senyawa yang ditunjukkan dengan adanya puncak-puncak yang terpisah. Profil senyawa antioksidan $H$. harveyana dapat dilihat pada Tabel 3. Berdasarkan kromatrogram tersebut ekstrak $H$. harveyana mengandung senyawa antioksidan berupa senyawa hidrokarbon aromatis dan ester yang mempunyai ikatan rangkap dan gugus hidroksi yang ditunjukkan pada senyawa no 4, 5, 7, 9, 10, 13, 14 dan 16. Menurut Oke \& Hamburger (2002) senyawa aromatik mengandung gugus hidroksi, khususnya ortho-di atau trihidroksi yang membentuk radikal cukup stabil. Adanya gugus hidroksi juga menjadi salah satu syarat agar suatu senyawa dapat memiliki aktivitas antioksidan. Adapun senyawa yang paling potensial sebagai antioksidan 
Tabel 3. Kemungkinan senyawa hasil analisis GC-MS ektrak $H$. harveyana segar

Table 3. Possible compounds of $\boldsymbol{H}$. harveyana fresh extract identified using GC-MS

\begin{tabular}{|c|c|c|c|c|c|}
\hline $\begin{array}{l}\text { Puncak/ } \\
\text { Peak }\end{array}$ & $\begin{array}{c}\text { Waktu } \\
\text { Retensi } \\
\text { Retention time } \\
\text { (menit/minute) }\end{array}$ & $\begin{array}{l}\text { Indeks } \\
\text { Kemiripan/ } \\
\text { Similary } \\
\text { Index }\end{array}$ & $\begin{array}{l}\text { Nama Senyawal } \\
\text { Compound name }\end{array}$ & $\begin{array}{l}\text { Rumus } \\
\text { molekul }\end{array}$ & $\begin{array}{c}\text { Berat } \\
\text { molekul/ } \\
\text { Molecular } \\
\text { weight }\end{array}$ \\
\hline 1 & 4.832 & 95 & Nitrous Oksoid & $\mathrm{N}_{2} \mathrm{O}$ & 44 \\
\hline 2 & 5.317 & 98 & Bromo methane & $\mathrm{CH}_{3} \mathrm{Br}$ & 94 \\
\hline 3 & 9.617 & 99 & 1- Butanol & $\mathrm{C}_{4} \mathrm{H}_{10}$ & 74 \\
\hline 4 & 19.308 & 96 & 1,2,4-trime thil benzen & $\mathrm{C}_{9} \mathrm{H}_{12}$ & 120 \\
\hline 5 & 19.983 & 96 & 1-methil-3-propil benzen & $\mathrm{C}_{10} \mathrm{H}_{14}$ & 134 \\
\hline 6 & 24.125 & 85 & $\begin{array}{l}\text { 2-methyl-2,3 dimethyl propil } \\
\text { ester }\end{array}$ & $\mathrm{C}_{12} \mathrm{H}_{24} \mathrm{O}_{3}$ & 216 \\
\hline 7 & 24.358 & 88 & $\begin{array}{l}\text { 2-me thyl,3-hidroksi-2,4,4- } \\
\text { trime thilpenthill ester }\end{array}$ & $\mathrm{C}_{102} \mathrm{H}_{10} \mathrm{O}_{3}$ & 216 \\
\hline 8 & 25.225 & 96 & 1,2 dimethil ester & $\mathrm{C}_{10} \mathrm{H}_{10} \mathrm{O}_{4}$ & 194 \\
\hline 9 & 25.993 & 85 & 2-Siklopenten1-one & $\mathrm{C}_{10} \mathrm{H}_{10} \mathrm{O}_{2}$ & 162 \\
\hline 10 & 26.017 & 81 & 2-Siklopenten-one & $\mathrm{C}_{10} \mathrm{H}_{10} \mathrm{O}_{2}$ & 162 \\
\hline 11 & 26.183 & 72 & 1-kloro-tetradekan & $\mathrm{C}_{14} \mathrm{H}_{29} \mathrm{Cl}$ & 232 \\
\hline 12 & 26.408 & 74 & Trimethilsili ester & $\mathrm{C}_{13}$ & 238 \\
\hline 13 & 26.583 & 76 & $\begin{array}{l}\text { 6-tert-buthyl-2,4 dimethyl } \\
\text { phenol }\end{array}$ & $\mathrm{C}_{12} \mathrm{H}_{18} \mathrm{O}$ & 178 \\
\hline 14 & 27.175 & 76 & 4-alil-1,6 heptadie ne-4-ol & $\mathrm{C}_{10} \mathrm{H}_{16} \mathrm{O}$ & 152 \\
\hline 15 & 29.942 & 95 & Methyl ester & $\mathrm{C}_{15} \mathrm{H}_{30} \mathrm{O}_{2}$ & 242 \\
\hline 16 & 30.783 & 69 & $\begin{array}{l}\text { 13,16-seko-D-nor-5 alpha- } \\
\text { androsta } 13(18), 15-\text { diene }\end{array}$ & $\mathrm{C}_{18} \mathrm{H}_{28}$ & 244 \\
\hline 17 & 34.558 & 97 & 3-Siklohexxane & $\mathrm{C}_{17} \mathrm{H}_{34} \mathrm{O}_{2}$ & 270 \\
\hline 18 & 36.633 & 70 & 3-Siklohexane & $\mathrm{C}_{12} \mathrm{H}_{16} \mathrm{O}_{2}$ & 192 \\
\hline 19 & 36.550 & 62 & Siklohexane & $\mathrm{C}_{9} \mathrm{H}_{11} \mathrm{~N}$ & 133 \\
\hline 20 & 37.108 & 68 & $\begin{array}{l}\text { 4-(2,2 dimethyl -6-methiliden- } \\
\text { 1-sikloheksiliden) }\end{array}$ & $\mathrm{C}_{14} \mathrm{H}_{22} \mathrm{O}$ & 206 \\
\hline
\end{tabular}

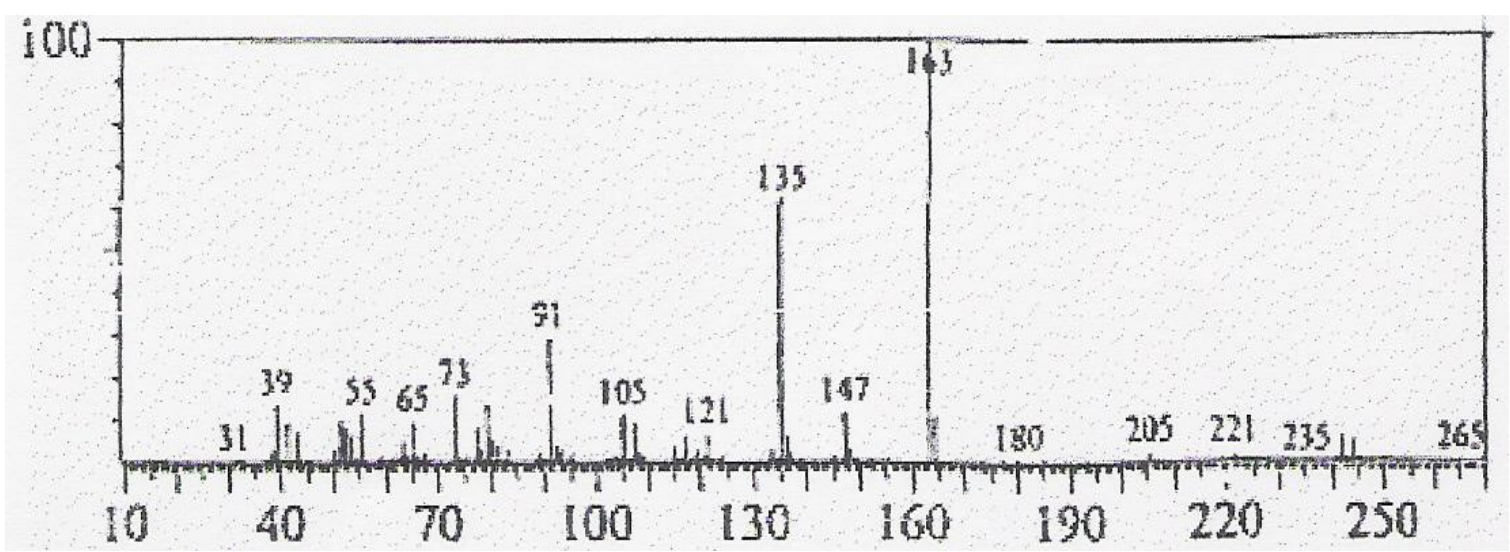

Gambar 6A. Spektra massa ekstrak Halymenia harveyana.

Figure $6 A$. Mass spectra of extract of Halymenia harveyana 


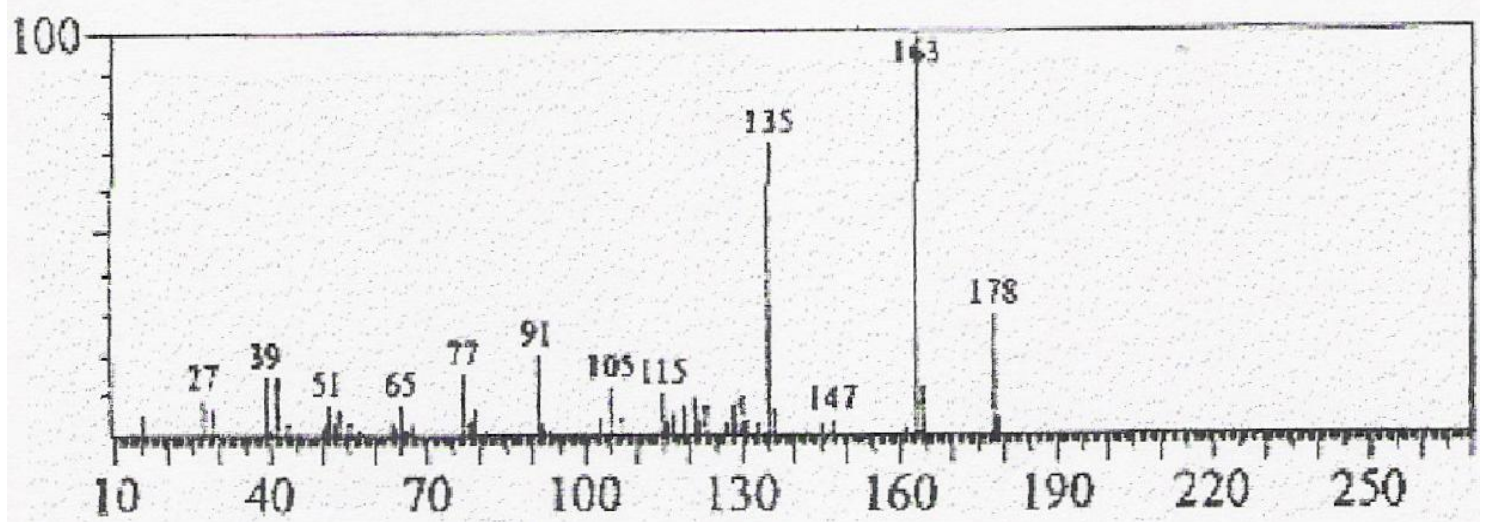

Gambar 6B. Spektra massa Butil Hidroksi Toluen (BHT) berdasarkan Lybrary NIST 62.

Figure 6B. Mass spectra of butyl hydroxy toluen based on lybrary NSIT 62.

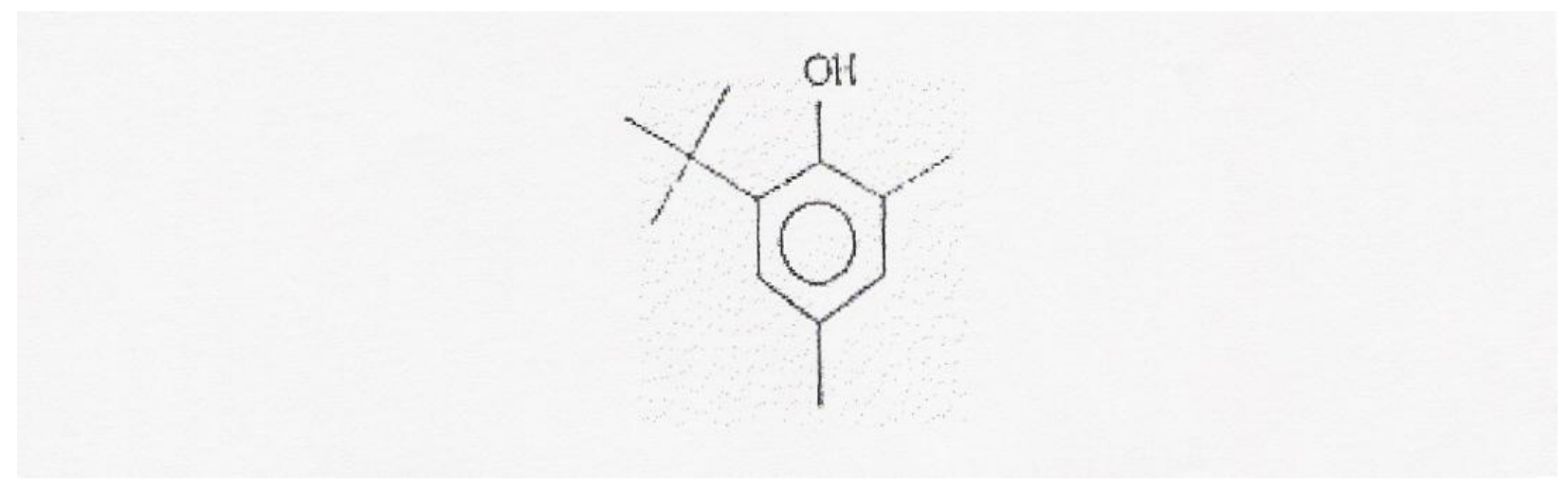

Gambar 6C. Rumus bangun Butil Hidroksi Toluen (BHT) dari lybrary NIST 62

Figure 6C. Configuration of Butyl Hydroxy Toluen (BHT) from lybrary NIST 62.

pada ekstrak $H$. harveyana ditunjukkan oleh puncak nomor 13 yaitu senyawa 6-tert-butil-2,4-dimetilfenol, yang mempunyai spektrum mirip dengan antioksidan jenis BHT (Butil Hidroksi Toluen), seperti terlihat pada Gambar 6A, dan 6B. Berdasarkan kedua spektra masa tersebut tampak adanya pemisahan puncak-puncak pada bilangan gelombang yang hampir sama antara spektra massa sampel dengan spektra massa BHT yang terdapat pada Library NIST 62 dengan indek kemiripan $76 \%$ dengan rumus molekul seperti Gambar 6C. Senyawa yang mirip dengan BHT juga dijumpai pada rumput laut merah jenis Porphyra yang dapat berfungsi sebagai aktivitas antioksigenik (Arabei, 2000). BHT merupakan antioksidan phenolik yang banyak digunakan untuk mengawetkan minyak sayur.
Senyawa ini dapat menghambat oksidasi lemak yang merupakan penyebab terjadinya ketengikan pada makanan selama proses penyimpanan dan pengolahan. (Angelo, 1996). Untuk lebih memastikan tentang struktur senyawa antioksidan dalam ekstrak tersebut maka perlu dilakukan pemurnian senyawa aktif yang selanjutnya dianalisis menggunakan FTIR dan NMR.

Dari hasil kromatogram fraksi metanol yang diekstrak dari E. cottonii segar diperoleh 30 puncak terpisah yang didominasi oleh derivat senyawa benzen seperti terlihat pada Tabel 4. Pada tabel tersebut terlihat adanya potensi senyawa antioksidan yang sangat besar yaitu senyawa no. 3-22, no. 25, dan no. 28-29. Senyawa antioksidan ini memberikan 
Tabel 4. Kemungkinan senyawa hasil analisis GC-MS ektrak E. cottonii segar Table 4. Possible compounds of E. cottonii fresh extract identified using GC-MS

\begin{tabular}{|c|c|c|c|c|c|}
\hline $\begin{array}{l}\text { Puncak } / \\
\text { Peak }\end{array}$ & $\begin{array}{c}\text { Waktu } \\
\text { retensi } \\
\text { Retention time } \\
\text { (menit/minute) }\end{array}$ & $\begin{array}{c}\text { Indeks } \\
\text { kemiripan/ } \\
\text { Similary } \\
\text { index }\end{array}$ & $\begin{array}{l}\text { Nama senyawa/ } \\
\text { Compound name }\end{array}$ & $\begin{array}{l}\text { Rumus } \\
\text { molekul }\end{array}$ & $\begin{array}{c}\text { Berat } \\
\text { molekul/ } \\
\text { Molecular } \\
\text { weight }\end{array}$ \\
\hline 1 & 5.033 & 96 & Kloromethan & $\mathrm{CH}_{3} \mathrm{Cl}$ & 50 \\
\hline 2 & 8.317 & 98 & Bromomethan & $\mathrm{CH}_{3} \mathrm{Br}$ & 94 \\
\hline 3 & 9.617 & 98 & Butyl Alkohol & $\mathrm{C}_{3} \mathrm{H}_{10} \mathrm{O}$ & 74 \\
\hline 4 & 19.308 & 96 & 1,2,3 Trimethyl benzene & $\mathrm{C}_{9} \mathrm{H}_{12}$ & 120 \\
\hline 5 & 19.983 & 96 & 1-methyl-3 propil benzene & $\mathrm{C}_{10} \mathrm{H}_{14}$ & 134 \\
\hline 6 & 20.117 & 94 & 2-ethil-1,4 dimethyl benzene & $\mathrm{C}_{10} \mathrm{H}_{14}$ & 134 \\
\hline 7 & 20.625 & 97 & 4-ethil-1,2 dimethyl benzene & $\mathrm{C}_{10} \mathrm{H}_{14}$ & 134 \\
\hline 8 & 20.800 & 97 & 4 ethil-1,2 dimethyl benzene & $\mathrm{C}_{10} \mathrm{H}_{14}$ & 134 \\
\hline 9 & 21.338 & 96 & 1-methil-4-9 methyl ethil benzene & $\mathrm{C}_{10} \mathrm{H}_{14}$ & 134 \\
\hline 10 & 21.633 & 97 & $1,2,4,5$, tetra methyl benzene & $\mathrm{C}_{10} \mathrm{H}_{14}$ & 134 \\
\hline 11 & 21.725 & 97 & 1,2,3,4-tetra methyl benzene & $\mathrm{C}_{10} \mathrm{H}_{12}$ & 134 \\
\hline 12 & 22.225 & 92 & 2.3-dihidro-4-methyl inden & $\mathrm{C}_{10} \mathrm{H}_{10}$ & 132 \\
\hline 13 & 22.492 & 90 & 1-ethenil-3-ethenil benzene & $\mathrm{C}_{20} \mathrm{H}_{24}$ & 264 \\
\hline 14 & 22.558 & 94 & 1,2,3,4-tetra metal benzene & $\mathrm{C}_{10} \mathrm{H}_{14}$ & 134 \\
\hline 15 & 23.258 & 98 & Naphthalen & $\mathrm{C}_{10} \mathrm{H}_{8}$ & 128 \\
\hline 16 & 24.417 & 83 & 2-methil indanon & $\mathrm{C}_{10} \mathrm{H}_{10}$ & 146 \\
\hline 17 & 24.758 & 87 & 1-methyl-4-methyl propil benzene & $\mathrm{C}_{11} \mathrm{H}_{16}$ & 148 \\
\hline 18 & 26.950 & 88 & Sikloproeazulen & $\mathrm{C}_{15} \mathrm{H}_{24}$ & 204 \\
\hline 19 & 27. 250 & 89 & Isolongitoluen & $\mathrm{C}_{15} \mathrm{H}_{24}$ & 204 \\
\hline 20 & 27.475 & 90 & Longitoluen & $\mathrm{C}_{15} \mathrm{H}_{24}$ & 204 \\
\hline 21 & 28.767 & 73 & 1,4-dihidro-2,3-quinon salindion & $\mathrm{C}_{8} \mathrm{H}_{6} \mathrm{~N}_{2} \mathrm{O}_{2}$ & 162 \\
\hline 22 & 28.850 & 82 & $\begin{array}{l}\text { 2-siklopenten1-one-2-(4-methyl-2- } \\
\text { furil) }\end{array}$ & $\mathrm{C}_{10} \mathrm{H}_{10} \mathrm{O}_{2}$ & 162 \\
\hline 23 & 29.575 & 91 & Gamma- gurjunen & $\mathrm{C}_{15} \mathrm{H}_{24}$ & 204 \\
\hline 24 & 29.775 & 69 & Trisiklohexzane & $\mathrm{C}_{12} \mathrm{H}_{20}$ & 164 \\
\hline 25 & 29.867 & 93 & $\begin{array}{l}1,2,3,4 \text { tetrahidro, } 1,6 \text { dimethyl } \\
\text { naphthalene }\end{array}$ & $\mathrm{C}_{15} \mathrm{H}_{22}$ & 202 \\
\hline 26 & 29.992 & 90 & 1,2-diethyl ester & $\mathrm{C}_{12} \mathrm{H}_{14} \mathrm{O}_{4}$ & 222 \\
\hline 27 & 30.333 & 97 & 1,2 diethylester & $\mathrm{C}_{12} \mathrm{H}_{14} \mathrm{O}_{4}$ & 222 \\
\hline 28 & 34.442 & 81 & Aroma dendren & $\mathrm{C}_{15} \mathrm{H}_{24}$ & 204 \\
\hline 29 & 37.033 & 91 & 3,4 Diene cholesta & $\mathrm{C}_{24} \mathrm{H}_{44}$ & 368 \\
\hline 30 & 38.048 & 76 & Asam hexadekanoat & $\mathrm{C}_{37} \mathrm{H}_{24}$ & 691 \\
\hline
\end{tabular}


manfaat sangat besar bagi sistem metabolisme tubuh, khususnya untuk meredam radikal bebas. Senyawa antioksidan memiliki peran yang sangat penting dalam mencegah penyakit degeneratif dan antikanker akibat nonviral dan non bakterial, misalnya akibat zat simbiotik yang menimbulkan mutasi genetik atau DNA.

Pada Tabel 4 terdeteksi adanya senyawa-senyawa aromatis turunan benzen, ada suatu kemungkinan bahwa senyawa-senyawa tersebut terserap pada rumput laut dari lingkungan perairan sekitarnya yang sudah agak tercemar oleh minyak bumi. Rumput laut merupakan biota yang mengandung kadar serat tinggi dan dapat mengabsorbsi cemaran dari lingkungan hidupnya.

\section{KESIMPULAN}

Dari hasil penelitian ini dapat disimpulkan bahwa rumput laut segar mempunyai aktivitas antioksidan yang lebih tinggi dibandingkan dengan rumput laut kering. Fraksinasi baik dengan metanol maupun $n-$ heksan menyebabkan turunnya aktivitas antioksidan yang dihasilkan, kecuali pada fraksi metanol $H$. harveyana segar. Fraksi ini memiliki aktivitas antioksidan yang paling poten dibandingkan dengan ekstrak lainnya. Kedua jenis rumput laut yang diteliti menunjukkan aktivitas antioksidan yang rendah dengan $\mathrm{LC}_{50}>150 \mathrm{ug} / \mathrm{mL}$. Uji toksisitas menunjukkan bahwa ekstrak rumput laut kering mempunyai sifat yang sangat toksik terhadap Artemia salina dengan $\mathrm{LC}_{50}$ berkisar antara 1,63-27, $94 \mathrm{ug} / \mathrm{mL}(<30 \mathrm{ug} / \mathrm{mL})$. Ekstrak $H$. harveyana segar fraksi metanol mengandung berbagai senyawa antioksidan ester dan hidrokarbon aromatis, dan mengandung senyawa 6tert-butyl-2,4 dimethyl phenol yang mirip BHT. Ekstrak E. cottonii banyak mengandung senyawa antioksidan yang didominasi oleh derivat senyawa benzen.

\section{DAFTAR PUSTAKA}

Anonim. 2004. Antioksidan, radikal bebas dan penuaan. Http//www.kompas.com/kompas_cetak/0305/11/ fokus/306284.htm.

Anonymous, 1995. Drugs from the sea. Aqua Farm News. 8(5): 1-20.

Abdul. M. 2003. Peranan radikal bebas dan antioksidan dalam kesehatan dan penyakit. Http:// www.intisari.com/radikal.html

Angelo, A.J. 1996. Lipid oxidation in food. Crit. Rev. Food Sci. Nutri. 36. p. 175-224.

Arabei, I. Y. 2000. Vegetable from the sea. Http://www. Alkalize for Health, net.Library.html.

Burtin, P. 2006. Nutritional value of seaweeed. Electronic J. Environ. Agric. Food Chem. 5(3): 6. Http://EJEAF Che.Uvigo/index.html
Jan, P., Yanishhlieve N., and Gordu. M. 2001. Antioxidant in food. Practical application. CRC Press M. Boca Raton Boston. New York. Washington DC.

Jimenez-Escrig, A. and Goni, CL. 1999. Nutritional and Evaluation and Physiological Effects of Edible Seaweed. Arch Latinoam Nutr. 49: 114-120.

Jun, M.H.Y., Yu., J., Fong, X., Wan, C.S, Yang, C.T. and Ho. 2003. Comparison of antioxidant activities of isoflavones from kudzu root (Pueraria labata Ohwl). J. Food Sci. Institute of Technologist. 68(6): 21172122.

Ismail, A. and Hong, T.S. 2002. Antioxidant activity of selected commercial seaweeds. Mal. J. Nutr. 8(2): 167177.

Kardono, L.B. 2004. Prospecting On Marine Natural Products for Potensial Functional Foods and Bioactive Substance. Makalah disampaikan pada Forum Bioteknologi Kelautan dan Perikanan, Badan Riset Kelautan dan Perikanan. Departemen Kelautan dan Perikanan, 25 Maret 2004. 15 pp.

Lik Tong Tan, Williamson, R.T., and Erwick, W.H., 2000. cis,cis-and trans,trans-Ceratospongamide, new bioactive cyclic heptapeptides from Indonesian red alga ceratodictyon spongiosum and symbiotic sponge sigmadocia symbiotica. J. Org. Chem. 65: 419-425.

Mayer, B.N., Ferrini, N.R., Putman, J.E., Jacobsen, L.B. Nichols, D.E. and Mc Laughin, J.L. 1982. A convenient general bioassay for active plant constituents. Planta Medica, 45: 31-34.

McLaughlin, J.L. and Roger, L.L. 1998. The Use of Biological Assay to evaluate botanicals. Drug Info. J. 32: 513-524.

Misonou, T., Saitoh, J., Oshiba, S., Tokitomo, Y., Maegawa, M., Inoue, Y., Hori, H., and Sakurai, T., 2003. UV-absorbing substance in red alga porphyra yezoensis (Bangiales, Rhodophyta) block thymine photodimer production. Mar. Biotechnol. 5: 194-200.

Nontji, A. 1996. Indonesian potensial in developing marine biotechnology. In: Proceeding on The First Indonesia Seminar on Marine Biotechnology.

Oke, J.M. and Hamburger, M.O. 2002. Screening of some Nigerian medicinal plants for antioxidant activity using DPPH radical. Afr. J. Biomed. Res. 5: 77-79.

Polteraid, O. 1997. Antioxidants and free radical scavengers of natural origin. Current Org. Chem 1. p. 415440.

Shoeib, N.A., Bibby, M.C., Blunden, G., Linley, P.A., Swaine, D.J., Wheelhouse, R.T., and Wright, C.W. 2004. Invitro cytotoxic activities of the major bromphenols of the red alga polysiphonia lanosa and some novel synthetic isomers. Am. Chem. Soc. and Am. Soc. Pharmacog. Web 00/00/0000. Page EST: 4.7

Siriwardhana, N., Lee, K.W. and Kim, S.H. 2003. Antioxidant activity of hizikia fusiformis on reactive oxygen 
species scavenging and lipid peroxidation inhibition. Yan, X, Nagata, T. and Fax, X. 1998. Antioxidative activiFood Sci. \& Technol. Int. (5): 339-348. ties in some common seaweeds. Plant Food Human Nutritional. 52(3): 253-262. 
